\title{
Synthesis and Antimicrobial Activities of Some New Sulfonyl Phenoxides
}

\author{
Oluwaseyi B Ovonramwen ${ }^{1 *}$, Bodunde J Owolabi ${ }^{1}$ and Abiodun Falodun ${ }^{2}$ \\ $1^{*}$ Department of Chemistry, Faculty of Physical Sciences, University of Benin, P.M.B. 1154, \\ Benin City, Edo State, Nigeria. \\ ${ }^{2}$ Department of Pharmaceutical Chemistry, Faculty of Pharmacy, University of Benin, Nigeria. \\ *Corresponding author e-mail: adebuloyeoluwaseyi@yahoo.com \\ Co-authore-mails: owolabibodunde@yahoo.com (Owolabi); faloabi@uniben.edu (Falodun) \\ Received 30 Jan 2021, Revised 13 May 2021, Accepted 19 May 2021, Published May 2021 \\ DOI: https://dx.doi.org/10.4314/tjs.v47i2.30
}

\begin{abstract}
Four new sulfonyl phenoxides were synthesized through $O$-sulfonylation reaction of phenolic compounds with 5-chloro-1-ethyl-2-methylimidazole-4-sulfonyl chloride in good yield. FT-IR, ${ }^{1} \mathrm{H}-\mathrm{NMR},{ }^{13} \mathrm{C}-\mathrm{NMR}$, and DEPT $135 \mathrm{NMR}$ were carried out to characterize and the thin layer chromatography (TLC) confirm the purity. Antimicrobial activities of the sulfonyl phenoxides against Gram-positive (methicillin-susceptible Staphylococcus aureus, methicillin-resistant Staphylococcus aureus, and Bacillus subtilis), Gram-negative (Pseudomonas aeruginosa, Escherichia coli, Klebsiella pneumoniae), and Candida albicans were carried out using the standard microbiological method. The antimicrobial activities were referenced to ciprofloxacin and itraconazole, antibacterial and antifungal drug respectively. The in vitro antimicrobial studies of 5-chloro-1-ethyl-2-methyl-1H-imidazole-4-sulfonyl(4-chloro-3-methyl)phenoxide and 5-chloro1-ethyl-2-methyl-1 $H$-imidazole-4-sulfonyl-2-methylphenoxide showed moderate activity against C. albicans. The four sulfonyl phenoxides had weak activities against Gram-positive and Gramnegative bacteria.
\end{abstract}

Keywords: Sulfonyl phenoxides, Antimicrobial, Phenolic compounds, $O$-Sulfonylation reaction.

\section{Introduction}

Sulfonyl-functional group compounds are sulfones, sultones, sulfonamides, and sulfonyl phenoxides. Sulfonyl phenoxides are readily synthesized from alcohols and sulfonyl halides via nucleophilic substitution reaction. Sulfonyl chlorides are highly reactive electrophile but easily hydrolyzed. Sulfonyl phenoxides have broad applications in synthetic chemistry, pharmaceuticals, and agrochemicals. Some sulfonyl phenoxides are bioactive compounds (Fernandes et al. 2020). In pharmaceutical industries, sulfonyl phenoxides have antimicrobial (Aneja et al. 2018, Krishna 2018, Rendošová et al. 2018), anti-inflammatory (Arshia et al. 2019), anti-cancer activities
(Rendošová et al. 2018, Du et al. 2019, Kanabar et al. 2020), etc.

Phenolic compounds are chemical component of flowers, fruits, vegetables, cereals, grains, and seeds. They have hydroxyl group and other substituents at different positions on the compounds. Phenolic compounds have been studied for their numerous properties, namely chemicals, biologicals, agricultural, and medical properties. Many phenolic compounds are used in food, pharmaceutical, and cosmetics production because of their organoleptic properties; color, aroma, taste, and astringency. In general, they are potent anti-oxidant (Zargoosh et al. 2019), anti-cancer (El-Ansari 
et al. 2019), anti-atherosclerotic (Lutz et al. 2019), anti-inflammatory (Sato et al. 2020), anti-microbial (Bouarab-Chibane et al. 2019), anti-gout (Abu Bakar et al. 2018), anti-obesity (Yen et al. 2020), and anti-HIV (Krishna et al. 2020)

As part of our interest in developing $O$ sulfonylation reaction of phenolic compounds, this paper herein presents four sulfonyl phenoxides (5-Chloro-1-ethyl-2-methyl-1Himidazole-4-sulfonyl(4-chloro-3-

methyl)phenoxide, 5-Chloro-1-ethyl-2-methyl$1 H$-imidazole-4-sulfonyl-2-methylphenoxide, 5-Chloro-1-ethyl-2-methyl- $1 \mathrm{H}$-imidazole-4sulfonyl-2,4,6-trinitrophenoxide, 5-Chloro-1ethyl-2-methyl-1H-imidazole-4-sulfonyl-(Z)-4(3-oxo-3-phenylprop-1-en-1-yl)phenoxide) synthesized from 5-chloro-1-ethyl-2methylimidazole-4-sulfonyl chloride and phenolic compounds. The synthesized compounds were screened for antimicrobial activities against Gram-positive bacteria (methicillin-susceptible Staphylococcus aureus (MSSA), methicillin-resistant Staphylococcus aureus (MRSA), and Bacillus subtilis), Gramnegative bacteria (Pseudomonas aeruginosa, Escherichia coli, Klebsiella pneumoniae), and Candida albicans.

\section{Materials and Methods}

All chemicals were analytical grade. Thin layer chromatography (TLC) determinations were performed on aluminum plate silica gel coated with florescent indicator $\mathrm{F}_{254} \quad(0.25 \mathrm{~mm}$ Kieselgel 60) in a solvent system (ethylacetate, hexane, petroleum ether, and methanol). FT-IR spectra were recorded using a CARY 630 instrument (Agilent Technologies, USA). Proton and carbon nuclear magnetic resonance $\left({ }^{1} \mathrm{H}\right.$ and ${ }^{13} \mathrm{C}$ NMR) spectra were recorded on a Bruker Avance $500 \mathrm{MHz}$ spectrometer. DEPT 135 NMR spectra were recorded to determine the presence of $\mathrm{CH}_{2}$. Chemical shifts for protons and carbons were reported in parts per million downfield from tetramethylsilane and were referenced to residual deuterated protium and the carbon resonance in the NMR solvent $\left(\mathrm{CDCl}_{3}=\delta 7.26\right.$ and 77.22 or $\mathrm{CD}_{3} \mathrm{OD}=\delta$
4.70). Chemical shift data of multiplicity were presented as ( $\mathrm{s}=$ singlet, $\mathrm{d}=$ doublet, $\mathrm{t}=$ triplet, $\mathrm{q}=$ quartet, $\mathrm{m}=$ multiplet), coupling constants are reported in Hertz $(\mathrm{Hz})$.

\section{Methods}

4-Hydroxychalcone: To a mixture of $\mathrm{NaOH}$ (1.00 g, $0.025 \mathrm{~mol})$, water $(10 \mathrm{~mL})$, and ethanol $(5 \mathrm{~mL})$ at $0-5{ }^{\circ} \mathrm{C}$ was added distilled acetophenone $(2.60 \mathrm{~g}, 0.022 \mathrm{~mol})$ and then 4hydroxybenzaldehyde $(2.64 \mathrm{~g}, 0.022 \mathrm{~mol})$ portion-wise with constant stirring. The reaction was maintained at $0-5{ }^{\circ} \mathrm{C}$ for $3 \mathrm{~h}$, the mixture was kept in the refrigerator overnight and acidified with conc. $\mathrm{HCl}(3 \mathrm{~mL}, 12 \mathrm{M})$, washed with cold water until neutral to litmus and recrystallized from ethanol to afford pale yellow solid: $3.09 \mathrm{~g}, 62.71 \%$; $\mathrm{R}_{f}, 0.40$ (EtOAc: hex, 3:7), m.p. $182-183{ }^{\circ} \mathrm{C}$ (lit, $182-183{ }^{\circ} \mathrm{C}$, Shubhalaxmi et al. 2013); FT-IR (ATR, neat, $\left.V_{\max } \mathrm{cm}^{-1}\right): 3300(\mathrm{OH}$, brd), 3012 (Aromatic ring $), 1655(\mathrm{C}=\mathrm{O}), 1578,1501(\mathrm{C}=\mathrm{C}, \mathrm{str}), 1460$ (ring C-H), 1413, 1348, 1206, 1167, 1126, 999, 845, 712, 693; ${ }^{1} \mathrm{H}$ NMR (500 MHz, $\mathrm{CDCl}_{3}, \delta$ in ppm): $5.87(\mathrm{~s}, \mathrm{OH}), 7.32-7.33(\mathrm{~d}, 2 \mathrm{H}, J=5$ $\mathrm{Hz}, m-\mathrm{CH}$, O-phenyl), 7.47 (s, 2H, o-CH, Ophenyl), 7.52-7.54 (t, $2 \mathrm{H}, \mathrm{CH}, J=5$ and $5 \mathrm{~Hz}$, $m$-CO-phenyl), 7.59-7.60 (d, CH, $J=5 \mathrm{~Hz}, p$ $\mathrm{CH}-\mathrm{CO}$-phenyl), 7.72 (s, $2 \mathrm{H}, o-\mathrm{CH}, \mathrm{CO}-$ phenyl), $7.74-7.75$ (d, H, $J=5 \mathrm{~Hz}, \mathrm{H}-\alpha$ ), 8.008.01 (d, H, $J=5 \mathrm{~Hz}, \mathrm{H}-\beta)$.

$N, \quad N^{1}$-diethyloxamide (II): Diethyl oxalate (I) $(30 \mathrm{~mL})$ was added drop-wise to a chilled $70 \%$ ethylamine $(33 \mathrm{~mL})$ with constant stirring. The white crystals formed were filtered, triturated in cold water, and air-dried to produce $N, N^{l}$-diethyloxamide (II): $26.04 \mathrm{~g}$, $83 \%$; $\mathrm{R}_{f}, 0.55$ (EtOAc: hex, 3:7); m.p. 179-180 ${ }^{\circ} \mathrm{C}$ (lit, $180-181{ }^{\circ} \mathrm{C}$, Trout 1966); FTIR: 3287, 2859, 1638, 1377, 1226, 1148, 821, and 770 $\mathrm{cm}^{-1}$.

\section{5-Chloro-1-ethyl-2-methylimidazole}

(III): A mixture of $N, N^{l}$-diethyloxamide (II) $(24 \mathrm{~g}, 0.17 \mathrm{~mol})$ and $\mathrm{PCl}_{5}(72 \mathrm{~g}, 0.35 \mathrm{~mol})$ in a 250-mL flat bottom flask equipped with a wide-open reflux condenser fitted to calcium chloride guard tube was stirred until a brownish solution was formed and then immersed in hot 
water for $30 \mathrm{~min}$. The solution was left overnight at room temperature. And then, the solution was chilled and made alkaline with $\mathrm{Na}_{2} \mathrm{CO}_{3}(4.72 \mathrm{M}, 45 \mathrm{~mL})$ to afford dark brown organic layer (III) (18.30 g) which separated with the help of an in situ sodium chloride formed (salting-out liquid-liquid extraction) and was pipetted out without further work up.

$\mathrm{C}_{6} \mathrm{H}_{9} \mathrm{ClN}_{2} \mathrm{~S}$ : dark brown oil; yield $75.51 \%$; $\mathrm{R}_{f,} 0.83\left(\mathrm{CHCl}_{3}\right)$; FT-IR (ATR, neat, $V_{\max } \mathrm{cm}^{-}$ 1): 2981, 2859, 1638, 1508, 1495, 1430, 1383, 1260, 1148, 820 and $660 \mathrm{~cm}^{-1} ;{ }^{1} \mathrm{H}$ NMR (500 $\mathrm{MHz}, \mathrm{CDCl}_{3}, \delta$ in ppm): $1.30-1.31(\mathrm{t}, J=5 \mathrm{~Hz}$, $\left.3 \mathrm{H}, \mathrm{CH}_{3}\right), 2.40\left(\mathrm{~s}, 3 \mathrm{H}, \mathrm{CH}_{3}\right), 3.95-3.99$ (q, 2 $\mathrm{H}, \mathrm{CH}_{2}$ ), 6.79-6.80 (s, H, NH).

5-Chloro-1-ethyl-2-methylimidazole-4sulfonyl chloride (IV): In a $250 \mathrm{~mL}$ flat bottom flask equipped with reflux condenser, chilled distilled chlorosulphonic acid $(67.5 \mathrm{~mL}$, $1.02 \mathrm{~mol})$ was carefully added to 5-chloro-1ethyl-2-methylimidazole (III) (15 g, $0.10 \mathrm{~mol})$, portion-wise. The mixture was fitted to a calcium chloride guard tube and then heated under reflux for $3 \mathrm{~h}$. The solution was cooled, poured in crushed ice and filtered immediately to get the product (IV) ( $9 \mathrm{~g}$ ) (Ovonramwen et al. 2020).

$\mathrm{C}_{6} \mathrm{H}_{8} \mathrm{Cl}_{2} \mathrm{~N}_{2} \mathrm{O}_{2} \mathrm{~S}$ : brown powder; yield 53.52\%; m.p. $116-117{ }^{\circ} \mathrm{C} ; \mathrm{R}_{f}, 0.89\left(\mathrm{CHCl}_{3}\right)$; FTIR: 2981, 2853, 1638, 1508, 1498, 1437, 1377, 1351, 1263, 1226, 1187, 1142, 787, 722, $666 \mathrm{~cm}^{-1}$; ${ }^{1} \mathrm{H}$ NMR $\left(500 \mathrm{MHz}, \mathrm{CDCl}_{3}, \delta\right.$ in ppm): $1.29-1.30$ (t, $\left.3 \mathrm{H}, J=10 \mathrm{~Hz}, \mathrm{CH}_{3}\right), 2.39$ (s, $3 \mathrm{H}, \mathrm{CH}_{3}$ ), 3.95-4.01 (q, $2 \mathrm{H}, \mathrm{CH}_{2}$ ).

Sulfonyl phenoxides: An equimolar mixture $(0.005 \mathrm{~mol})$ of 5-chloro-4chlorosulfonyl-1-ethyl-2-methylimidazole (IV) $(1.22 \mathrm{~g})$ and phenolic compound were dissolved in $20 \mathrm{~mL}$ of $10 \% \mathrm{Na}_{2} \mathrm{CO}_{3}$ (base, $10 \%$ $\mathrm{NaOH}$; temperature, $70-80{ }^{\circ} \mathrm{C}$ ). The mixture was stirred at $300 \mathrm{rpm}, 25-28^{\circ} \mathrm{C}$ for $12 \mathrm{~h}$. The crude product was collected by filtration, washed with cold water, and recrystallized from ethanol to afford the respective sulfonyl phenoxides (V) (Scheme 1).<smiles>CCOC(=O)C(=O)OCC</smiles>

(I)

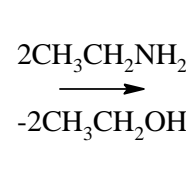<smiles>CCNC(=O)C(=O)NCC</smiles>

(II)

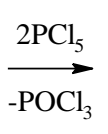<smiles>CCn1c(Cl)cnc1C</smiles>

(III)

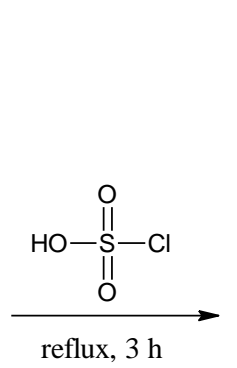<smiles>CCn1c(C)nc(S(=O)(=O)Cl)c1Cl</smiles>

(IV)

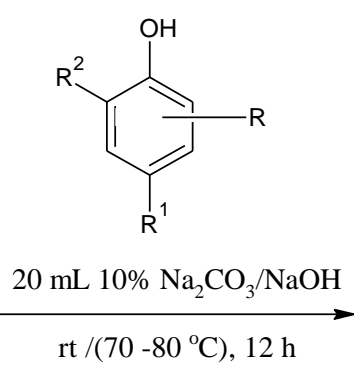

$\mathrm{rt} /\left(70-80^{\circ} \mathrm{C}\right), 12 \mathrm{~h}$<smiles>[R7]c1ccc(OS(=O)(=O)c2nc(C)n(CC)c2Cl)c([R7])c1</smiles>

(V)

\begin{tabular}{c|c|c|c} 
Compounds & \multicolumn{1}{c}{$\mathbf{R}$} & \multicolumn{1}{c}{$\mathbf{R}^{\mathbf{1}}$} & \multicolumn{2}{c}{$\mathbf{R}^{2}$} \\
\hline $\mathbf{1}$ & $m-\mathrm{CH}_{3}$ & $\mathrm{Cl}$ & $\mathrm{H}$ \\
$\mathbf{2}$ & $o-\mathrm{CH}_{3}$ & $\mathrm{H}$ & $\mathrm{H}$ \\
$\mathbf{4}$ & $2-\mathrm{NO}_{2}$ & $4-\mathrm{NO}_{2}$ & $6-\mathrm{NO}_{2}$ \\
\hline
\end{tabular}

Scheme 1: Synthesis of sulfonyl phenoxides. 
5-Chloro-1-ethyl-2-methyl-1H-imidazole4-sulfonyl(4-chloro-3-methyl)phenoxide (1): $\mathrm{C}_{13} \mathrm{H}_{14} \mathrm{Cl}_{2} \mathrm{~N}_{2} \mathrm{O}_{3} \mathrm{~S}$; off white solid; yield, 97.70\%; m.p. $128-129{ }^{\circ} \mathrm{C} ; \mathrm{R} f, 0.71$ (EtOAc: Pet, 3:1); FT-IR (ATR, neat, $V_{\max } \mathrm{cm}^{-1}$ ): 2982 $\left(\mathrm{CH}_{3}\right), 1651,1603(\mathrm{C}=\mathrm{N}$, wk $), 1528,1506$ $(\mathrm{C}=\mathrm{C}$, str), 1491 (ring $\mathrm{C}-\mathrm{H}), 1372\left(\mathrm{~S}=\mathrm{O}, \mathrm{SO}_{2}\right.$ as, str), 1260 (C-N bend, str), 1223, 1170 ( $\mathrm{S}=\mathrm{O}, \mathrm{SO}_{2}$ sy, str), 1122 (C-O str), 1058, 1003, 943, 872 (S=O, str), 824 (S-O, str), 798, 667 (C-Cl str); ${ }^{1} \mathrm{H}$ NMR $\left(500 \mathrm{MHz}, \mathrm{CDCl}_{3}, \delta\right.$ in ppm): $1.26-1.30$ (t, $J=10$ and $10 \mathrm{~Hz}, 3 \mathrm{H}$, $\mathrm{CH}_{3}$, imidazole), 2.28 (s, $3 \mathrm{H}, \mathrm{CH}_{3}$, phenyl), 2.43 (s, 3H, $\mathrm{CH}_{3}$, imidazole), 3.92-3.98 (q, $J=$ $10 \mathrm{~Hz}, 2 \mathrm{H}, \mathrm{CH}_{2}$, imidazole), 6.86-6.87 (d, $J=5$ Hz, H, o-phenyl), 7.04 (s, H, o-phenyl) 7.21$7.23\left(\mathrm{~d}, J=10 \mathrm{~Hz}, \mathrm{H}, m\right.$-phenyl); ${ }^{13} \mathrm{C} \mathrm{NMR}$ $\left(\mathrm{CDCl}_{3}, \delta\right.$ in ppm): $13.85\left(\mathrm{CH}_{3}\right.$, imidazole $)$ $14.72\left(\mathrm{CH}_{3}\right.$, imidazole $), 20.18\left(\mathrm{CH}_{3}\right.$, phenyl), $40.20\left(\mathrm{CH}_{2}\right.$, imidazole), 120.80 (o-CH, phenyl), $123.08(\mathrm{C}-\mathrm{Cl}$ ), 124.60 (o-C, phenyl), 128.04 $\left(\mathrm{C}-\mathrm{SO}_{2}\right), 129.80$ ( $m$-C, phenyl), $132.78(p-\mathrm{C}$, phenyl) 137.71 ( $m$-CH, phenyl), 145.45 (C-2, imidazole), 147.70 (C-O-phenyl).

5-Chloro-1-ethyl-2-methyl-1H-imidazole4-sulfonyl-2-methylphenoxide

$\mathrm{C}_{13} \mathrm{H}_{15} \mathrm{ClN}_{2} \mathrm{O}_{3} \mathrm{~S}$; white solid; yield, 95.60\%; m.p. $96-97{ }^{\circ} \mathrm{C}$; Rf, 0.76 (EtOAc: Pet, 3:1); FTIR (ATR, neat, $V_{\max } \mathrm{cm}^{-1}$ ): 3060 (Ar, imidazole $\mathrm{C}-\mathrm{H}), 2986\left(\mathrm{CH}_{3}\right), 2937\left(\mathrm{CH}_{2}\right), 2762\left(\mathrm{CH}_{2}-\mathrm{N}\right)$ $1654(\mathrm{C}=\mathrm{N}), 1580,1528(\mathrm{C}=\mathrm{C}, \mathrm{str}), 1502$, 1439 (ring $\mathrm{C}-\mathrm{H}), 1371\left(\mathrm{~S}=\mathrm{O}, \mathrm{SO}_{2}\right.$ as, str), 1260 (C-N bend, str), 1178 ( $\mathrm{S}=\mathrm{O}, \mathrm{SO}_{2}$ sy, str), 1148, 1100 (C-O, str), 1025, 956, 861 ( $\mathrm{S}=\mathrm{O}, \mathrm{str}), 816$ (S-O, str), 787, 686 (C-Cl, str); ${ }^{1} \mathrm{H}$ NMR (500 $\mathrm{MHz}, \mathrm{CDCl}_{3}, \delta$ in ppm): $1.26-1.29$ (t, $J=10$ and $5 \mathrm{~Hz}, 3 \mathrm{H}, \mathrm{CH}_{3}$, imidazole), $2.22(\mathrm{~s}, 3 \mathrm{H}$ $\mathrm{CH}_{3}$, phenyl), 2.43 (s, $3 \mathrm{H}, \mathrm{CH}_{3}$, imidazole), 3.92-3.97 (q, $J=10 \mathrm{~Hz}, 2 \mathrm{H}, \mathrm{CH}_{2}$, imidazole), 7.08-7.16 (m, $4 \mathrm{H}$, phenyl); ${ }^{13} \mathrm{C} \mathrm{NMR}\left(\mathrm{CDCl}_{3}\right.$ $\delta$ in ppm): ${ }^{13} \mathrm{C} \mathrm{NMR}\left(\mathrm{CDCl}_{3}, \delta\right.$ in ppm): 13.83 $\left(\mathrm{CH}_{3}\right.$, imidazole $), 14.74\left(\mathrm{CH}_{3}\right.$, imidazole $), 16.33$ $\left(\mathrm{CH}_{3}\right.$, phenyl), $40.16\left(\mathrm{CH}_{2}\right.$, imidazole $), 122.21$ (o-CH, phenyl), $122.81(\mathrm{C}-\mathrm{Cl}), 126.86(p-\mathrm{CH}$, phenyl), 126.99 (o-C, phenyl), $128.80\left(\mathrm{C}-\mathrm{SO}_{2}\right)$, 131.49 ( $m$-CH, phenyl) 131.55 ( $m$ - $\mathrm{CH}$, phenyl), 145.28 (C-2, imidazole), 148.21 (C-O-phenyl).
5-Chloro-1-ethyl-2-methyl-1 $H$-imidazole4-sulfonyl-2,4,6-trinitrophenoxide (3): $\mathrm{C}_{12} \mathrm{H}_{10} \mathrm{ClN}_{5} \mathrm{O}_{9} \mathrm{~S}$; orange solid; yield, $83.43 \%$; m.p. $283-284{ }^{\circ} \mathrm{C}$; Rf, 0.63 (MeOH: Pet, 1:1); FT-IR (ATR, neat, $V_{\max } \mathrm{cm}^{-1}$ ): 3090 (Ar, imidazole C-H), $2982\left(\mathrm{CH}_{3}\right), 2822\left(\mathrm{CH}_{2}\right)$, $1633(\mathrm{C}=\mathrm{N}$, str), 1558 (C=C, str), 1491 (ring C$\mathrm{H}, \mathrm{NO}_{2}$ as, str), 1428, $1379\left(\mathrm{~S}=\mathrm{O}, \mathrm{SO}_{2}\right.$ as, str), $1331\left(\mathrm{NO}_{2}\right.$ sy, str), 1264 (C-N bend, str), 1200, 1159 ( $\mathrm{S}=\mathrm{O}, \mathrm{SO}_{2}$ sy, str), 1066 (C-NO, str), 932, 906, 850 (C-NO), 820 (S-O, str), 753, 708 (C$\mathrm{Cl}$ str); ${ }^{1} \mathrm{H}$ NMR $\left(500 \mathrm{MHz}, \mathrm{CD}_{3} \mathrm{OD}, \delta\right.$ in ppm): $1.20-1.23$ (t, $3 \mathrm{H}, J=5$ and $10 \mathrm{~Hz}, \mathrm{CH}_{3}$, imidazole), 2.31 (s, $3 \mathrm{H}), 3.91-3.97$ (q, $J=10$ $\mathrm{Hz}, 2 \mathrm{H}, \mathrm{CH}_{2}$, imidazole), 8.80 (s, $2 \mathrm{H}$, phenyl): ${ }^{13} \mathrm{C}$ NMR $\left(\mathrm{CD}_{3} \mathrm{OD}, \delta\right.$ in ppm) $12.46\left(\mathrm{CH}_{3}\right.$, imidazole $), 13.83\left(\mathrm{CH}_{3}\right.$, imidazole $), 39.62\left(\mathrm{CH}_{2}\right.$, imidazole), $116.39(\mathrm{C}-\mathrm{Cl}), 127.27(\mathrm{~m}-2 \mathrm{CH}-$ phenyl), $128.10 \quad\left(\mathrm{C}-\mathrm{SO}_{2}\right), 134.26 \quad(o-2 \mathrm{C}-$ phenyl), 141.20 (p-C-phenyl), 144.92 (C-2, imidazole), 162.65(C-O-phenyl).

5-Chloro-1-ethyl-2-methyl-1H-imidazole4-sulfonyl-(Z)-4-(3-oxo-3-phenylprop-1-en-1yl)phenoxide (4): $\mathrm{C}_{21} \mathrm{H}_{19} \mathrm{ClN}_{2} \mathrm{O}_{4} \mathrm{~S}$; yellow solid; yield, 20.93\%; m.p. $283-284{ }^{\circ} \mathrm{C}$; $\mathrm{R} f$, 0.52 (EtOAc: hex); FT-IR (ATR, neat, $V_{\max }$ $\left.\mathrm{cm}^{-1}\right): 2924\left(\mathrm{CH}_{3}\right), 2854\left(\mathrm{CH}_{2}\right), 1648(\mathrm{C}=\mathrm{O})$, $1595(\mathrm{C}=\mathrm{N}), 1578,1501(\mathrm{C}=\mathrm{C}, \mathrm{str}), 1460$ (ring $\mathrm{C}-\mathrm{H}), 1413,1379$ ( $\mathrm{S}=\mathrm{O}, \mathrm{SO}_{2}$ as, str), 1348, 1256 (C-N bend, str), 1206, $1195\left(\mathrm{~S}=\mathrm{O}, \mathrm{SO}_{2}\right.$ sy, str), 1167, 1145, 1126, 962 ( $\mathrm{S}=\mathrm{O}, \mathrm{str}), 845$ (S-O, str), 712, 693 (C-Cl, str); ${ }^{1} \mathrm{H}$ NMR (500 $\mathrm{MHz}, \mathrm{CDCl}_{3}, \delta$ in ppm): $1.30-1.34(\mathrm{t}, J=5$ and $10 \mathrm{~Hz}, 3 \mathrm{H}, \mathrm{CH}_{3}$, imidazole), $2.48(\mathrm{~s}, 3 \mathrm{H}$, $\mathrm{CH}_{3}$, imidazole), 3.95-4.00 (q, $J=10 \mathrm{~Hz}, 2 \mathrm{H}$, $\mathrm{CH}_{2}$, imidazole), 7.23-7.24 (d, J=5 Hz, $2 \mathrm{H}, o$ $\mathrm{CH}$, O-phenyl), 7.47 (s, $2 \mathrm{H}, m-\mathrm{CH}, \mathrm{O}$-phenyl), $7.50-7.52$ (t, CH, $J=5$ and $5 \mathrm{~Hz}, 2 \mathrm{H}, m-\mathrm{CO}-$ phenyl), 7.60-7.61 (d, $J=5 \mathrm{~Hz}, \mathrm{H}, p$-CH-COphenyl), 7.72 (s, $2 \mathrm{H}, o-\mathrm{CH}, \mathrm{CO}$-phenyl), 7.757.76 (d, $J=5 \mathrm{~Hz}, \mathrm{H}, \mathrm{H}-\alpha$ ), 8.00-8.01 (d, $J=5$ $\mathrm{Hz}, \mathrm{H}, \mathrm{H}-\beta) ;{ }^{13} \mathrm{C} \mathrm{NMR}\left(\mathrm{CDCl}_{3}, \delta\right.$ in ppm) $13.92\left(\mathrm{CH}_{3}\right.$, imidazole $), 14.77 \quad\left(\mathrm{CH}_{3}\right.$, imidazole), $40.21\left(\mathrm{CH}_{2}\right.$, imidazole), 122.80 ( $\mathrm{m}$ $2 \mathrm{CH}$, O-phenyl), 122.89 (C- $\alpha$, chalcone), $123.16(\mathrm{C}-\mathrm{Cl}), 122 \mathrm{H} 8.27$ (p-C, O-phenyl), 128.49 (2CH, o-CO-phenyl), $128.70\left(\mathrm{C}-\mathrm{SO}_{2}\right)$, 129.68 (2CH, $m$-CO-phenyl), 133.01 (2CH, $m$ - 
O-phenyl), 133.79 (CH, p-CO-phenyl), 137.92 (C, CO-phenyl), 143.08 (C-2, imidazole), 145.41 (C- $\beta$, chalcone), 150.87 (C-O-phenyl), $190.17(\mathrm{C}=\mathrm{O})$.

\section{Antimicrobial activities \\ Determination of zone of inhibition}

The microbial growth inhibitory activities of the synthesized sulfonyl phenoxides were determined by the agar well plate method where the compounds were initially dissolved in dichloromethane and distilled water $(1: 1)$. Those compounds with activities were later tested at concentrations of 10, 15, 20, 60 $\mathrm{mg} / \mathrm{mL}$ against clinical isolated Gram-positive bacteria (methicillin-susceptible $S$. aureus (MSSA), methicillin-resistant $S$. aureus (MRSA), and B. subtilis), Gram-negative bacteria ( $P$. aeruginosa, $E$. coli, $K$. pneumoniae), and $C$. albicans cultured and subcultured using the standard microbiological method. Sterile nutrient and Sabouraud dextrose agar plates were prepared for bacteria and fungi respectively and standardized inoculum of test organisms was spread uniformly.

Six wells were bored using a sterile borer ( 8 $\mathrm{mm}$ ) and $100 \mu \mathrm{L}$ of the test concentrations, standard antibiotic, and the solvent control were added to each well. The plates were left on the table for $1 \mathrm{~h}$ for the test solution to diffuse into the medium and then incubated at $37{ }^{\circ} \mathrm{C}$ for $18-24 \mathrm{~h}$. The resultant zone of inhibitions of microbial growth around the well was measured in $\mathrm{mm}$. The test was performed in triplicate. Standard antibiotics ciprofloxacin (30 $\mathrm{mg} / \mathrm{mL})$, and itraconazole $(50 \mathrm{mg} / \mathrm{mL})$ were tested against bacteria and fungi respectively as the positive control (Ovonramwen et al. 2020).

\section{Determination of minimum inhibitory concentration (MIC)}

The minimum inhibitory concentration (MIC) values of the sulfonyl phenoxides were determined using the agar dilution method. Four different concentrations range of $100 \mu \mathrm{L}$ of the synthesized compounds were incorporated into their respective molten agar and allowed to set. This was also repeated for ciprofloxacin and itraconazole as positive control and the diluent as a negative control. Each of the standardized test microorganisms was radially streaked onto the prepared plates. The plate was left to stand for $1 \mathrm{~h}$ at room temperature, incubated at $37{ }^{\circ} \mathrm{C}$ for $18-24 \mathrm{~h}$. The MIC was recorded as the lowest concentrations that inhibited the growth of each of the test organisms (Ovonramwen et al. 2020).

\section{Results and Discussion}

5-Chloro-1-ethyl-2-methylimidazole was synthesized from $N, N^{l}$-diethyloxamide via Wallach synthesis. A neat chlorosulfonylation reaction produced 5-chloro-1-ethyl-2methylimidazole-4-sulfonyl chloride. This was reacted with phenolic compounds in the $10 \%$ sodium carbonate or sodium hydroxide in an $\mathrm{S}_{N} 2$ reaction mechanism to afford sulfonyl phenoxides (1-4). The lone pair $\mathrm{sp}^{2}$ electrons of the phenolic compound $\mathrm{O}$ (nucleophile) attacked the electrophilic sulfur atom in 5chloro-1-ethyl-2-methylimidazole-4-sulfonyl chloride (electrophile) and pushed charge out onto its electronegative $\mathrm{O}$ atom. This produced the first intermediate. Then proton on the $\mathrm{O}$ of the protonated phenoxide-group was transferred to the negatively charged $\mathrm{O}$ of sulfonyl-group. $\mathrm{HCl}$ was eliminated from the second intermediate to produce sulfonyl phenoxides (Scheme 2). 


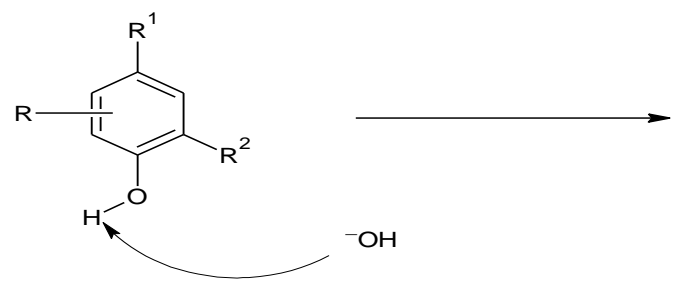<smiles>[R]C1=C[C]([O-])C([R])=C1</smiles>

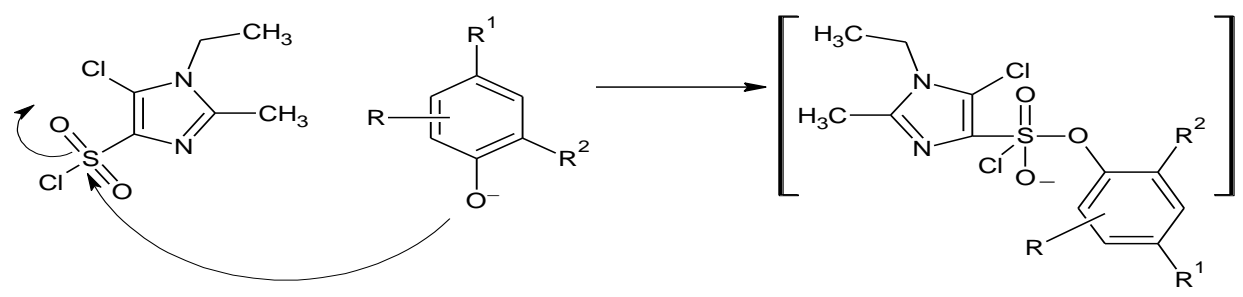

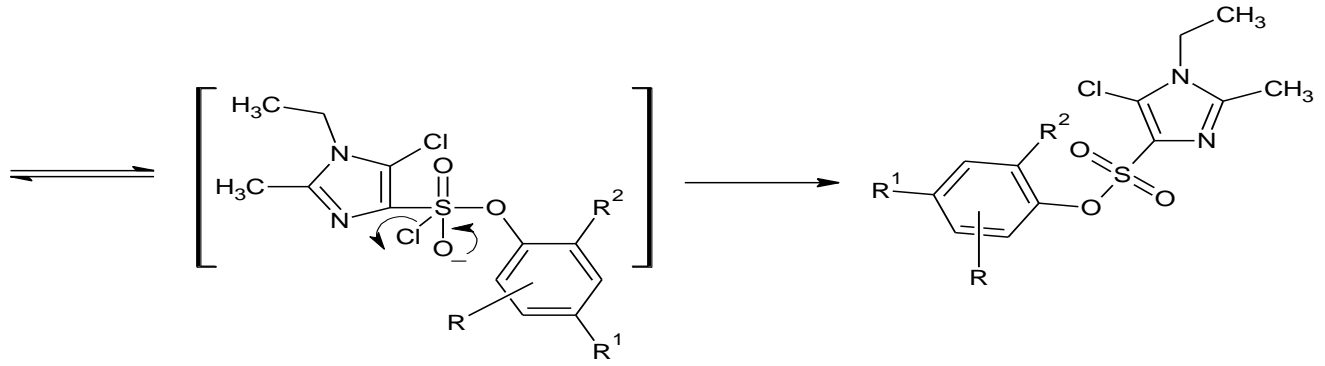

Scheme 2: Proposed mechanism for the sulfonyl phenoxides.

The synthesized compounds were assigned their structure by detailed analysis of FTIR, ${ }^{1} \mathrm{H}$, ${ }^{13} \mathrm{C}$ NMR, and DEPT (Figures S1-S16). Compound 4 was the only sulfonyl phenoxide prepared in the presence of $10 \%$ sodium hydroxide at $70-80{ }^{\circ} \mathrm{C}$. The compound's low yield $(20.93 \%)$ might be from the reaction conditions (Tingare et al. 2018, Álvarez et al. 2019).

In FTIR, the appearance of $1126-1066 \mathrm{~cm}^{-1}$ of $\mathrm{C}-\mathrm{O}$ vibrational stretching confirmed the formation of the sulfonyl phenoxides (Oliveira et al. 2016, Ovonramwen et al. 2020). The presence of $\mathrm{C}=\mathrm{O}$ group in compound $\mathbf{4}$ and aromatic $\mathrm{C}=\mathrm{C}$ group gave the absorption band at $1648 \mathrm{~cm}^{-1}$ and $1580-1528 \mathrm{~cm}^{-1}$, respectively. The FTIR were consistent with the published data (Rosa et al. 2019).

${ }^{1} \mathrm{H}$ NMR of the alkyl groups on imidazole ring appeared upfield as triplet, singlet and quartet in these orders with a coupling constant
$J \sim 10$ and $5 \mathrm{~Hz}$ for the triplet signal. The ethylenic protons of compound $\mathbf{4}$ appeared as doublets at 7.75-7.76 ppm and 8.00-8.01 ppm for $\mathrm{H}-\alpha$ and $\mathrm{H}-\beta$, respectively with a coupling constants $J \sim 5 \mathrm{~Hz}$. This confirmed cis configuration of vinylic protons. The aromatic protons appeared between 6.86 to $8.80 \mathrm{ppm}$. The protons on the C-O-phenyl of compounds 1 and 2 appeared upfield at 6.85-7.23 because of the electron-donating effect (+I effect) of methyl group. The $\mathrm{C}-\mathrm{O}$-phenyl of compound $\mathbf{3}$ signal appeared as a singlet with a downfield shift at $8.80 \mathrm{ppm}$ as result of electronwithdrawing effect ( $-\mathrm{I}$ effect) of the nitro groups at positions $\mathrm{C}-2, \mathrm{C}-4$, and $\mathrm{C}-6$. The $\mathrm{C}$ O-phenyl protons of compound 4 at $\delta 7.23-$ 7.47 ppm lied between those of compound 3 and compounds $\mathbf{1}$ and $\mathbf{2}$ because of enone group and extra phenyl of chalcone were less electronegative than the three nitro groups. 
In ${ }^{13} \mathrm{C}$ NMR spectra, $\mathrm{C}-\mathrm{Cl}, \mathrm{C}-\mathrm{SO}_{2}, \mathrm{C}-2$, and aromatic carbons appeared in these range; 116.39-123.16, 128.08-128.80, 143.08 145.45 , and aromatic ring 120.80-162.65 ppm, respectively. These were in line with literature values (Ovonramwen et al. 2020, SigmaAldrich 2021). The $\mathrm{C}=\mathrm{O}$ of compound 4 resonated at $190.17 \mathrm{ppm}$. This compared favorably with the literature data (Grosso et al. 2019, Rosa et al. 2019). The $\alpha$ - and $\beta$ - carbon atoms of the carbonyl appeared at 122.89 and $145.41 \mathrm{ppm}$ respectively. The C-O-phenyl of compound $\mathbf{3}$ appeared as most deshielded at $162.65 \mathrm{ppm}$ because of the electronwithdrawing effect of the nitro groups. The CO-phenyl signal of compound $\mathbf{1}$ and $\mathbf{2}$ resonated between $147.70-148.21$ as a result of electron-donating effect of methyl group. The C-O-phenyl signal of compound 4 lied at $150.87 \mathrm{ppm}$ between the signal of compound $\mathbf{3}$, and compounds $\mathbf{1}$ and $\mathbf{2}$.

The four newly synthesized compounds were tested for their antibacterial and anticandidal activities (Figure S17). The zone of inhibition for C. albicans using the cup-plate method on compound $\mathbf{1}$ and $\mathbf{2}$ gave $13.50 \pm$ $0.21 \mathrm{~mm}$ and $19.00 \pm 0.25 \mathrm{~mm}$ respectively and the standard itraconazole gave $21.50 \pm 0.37$ $\mathrm{mm}$ (Table 1). However, these activities might be because of the methyl group at ortho or meta position of the phenyl rings respectively. The MIC of the compounds $\mathbf{1}$ and $\mathbf{2}$ using the agar dilution method were $61.00 \pm 0.14 \mathrm{mg} / \mathrm{L}$ and $31.00 \pm 0.10 \mathrm{mg} / \mathrm{L}$ respectively. Compounds $\mathbf{3}$ and $\mathbf{4}$ had no antifungal activity against tested fungi as reported in previous studies (Shakhatreh et al. 2016, Ovonramwen et al. 2020). All the sulfonyl phenoxides showed no in vitro antibacterial activity against Gram-positive bacteria (MSSA, MRSA, and $B$. subtilis), Gram-negative bacteria ( $P$. aeruginosa, E. coli, $K$. pneumoniae) as reported in literature (Shakhatreh et al. 2016, Alhameed et al. 2020, Ovonramwen et al. 2020). Therefore, the sulfonyl phenoxides had no effect on the thickness of peptidoglycan layer of the bacterial cell wall and on the presence or absence of the outer lipid membrane.

Table 1: Zones of inhibition of sulfonylphenoxides and standard drugs in $\mathrm{mm}$

\begin{tabular}{|c|c|c|c|c|c|c|c|c|}
\hline & \multicolumn{8}{|c|}{ Average inhibition zone } \\
\hline Compounds & $\begin{array}{c}P \\
\text { aeruginosa }\end{array}$ & MRSA & MSSA & $\begin{array}{c}\text { E. } \\
\text { coli }\end{array}$ & $\begin{array}{c}\text {. } \\
\text { pneumoniae }\end{array}$ & $\begin{array}{c}\text { B. } \\
\text { subtilis(T) }\end{array}$ & $\begin{array}{c}B . \\
\text { subtilis }\end{array}$ & $\begin{array}{c}C . \\
\text { albicans }\end{array}$ \\
\hline 1 & - & - & - & - & - & - & - & 13.50 \\
\hline 2 & - & - & - & - & - & - & - & 19.00 \\
\hline 3 & - & - & - & - & - & - & - & - \\
\hline 4 & - & - & - & - & - & - & - & - \\
\hline Ciprofloxacin & 27.00 & 27.00 & 31.00 & 27.00 & 26.00 & 25.00 & 28.00 & \\
\hline Itraconazole & - & - & - & - & - & - & - & 21.50 \\
\hline
\end{tabular}

\section{Conclusions}

The four sulfonylphenoxides were synthesized under mild reaction conditions. 5-Chloro-1ethyl-2-methyl-1 $H$-imidazole-4-sulfonyl-(Z)-4(3-oxo-3-phenylprop-1-en-1-yl)phenoxide had low yield as a result of its cis-configuration and reaction conditions. The in vitro antimicrobial studies on 5-chloro-1-ethyl-2-methyl-1Himidazole-4-sulfonyl(4-chloro-3-

methyl)phenoxide and 5-chloro-1-ethyl-2methyl-1H-imidazole-4-sulfonyl-2- methylphenoxide showed moderate activities against C. albicans. All the sulfonyl phenoxides had weak activities against Grampositive and Gram-negative bacteria.

\section{Conflict of Interest}

The authors declare no conflict of interest.

\section{Acknowledgments}

Authors appreciate Dr. Zulfiqar Ali of University of Mississippi, USA for NMR 
characterization. And also, appreciate Dr. V. Imieje and Dr. O. Erharuyi who guided in sending the samples for characterization, while Dr. (Mrs) U. F. Babaiwa exposed to microbial analysis.

\section{References}

Abu Bakar FI, Abu Bakar MF, Rahmat A, Abdullah N, Sabran SF and Endrini S 2018 Anti-gout potential of malaysian medicinal plants. Front. Pharmacol. 9: 261.

Alhameed RA, Almarhoon Z, Bukhari SI, ElFaham A and de la Torre BG and Albericio F 2020 Synthesis and antimicrobial activity of a new series of thiazolidine-2,4-diones carboxamide and amino acid derivatives. Molecules 25(1): 105.

Álvarez MG, Crivoi DG, Medina F and Tichit D 2019 Synthesis of chalcone using LDH/graphene nanocatalysts of different compositions. Chem. Eng. 3(1): 29.

Aneja B, Azam M, Alam S, Perwez A, Maguire R, Yadava U, Kavanagh K, Daniliuc CG, Rizvi MMA, Haq QMR and Abid M 2018 Natural product-based 1,2,3triazole/sulfonate analogues as potential chemotherapeutic agents for bacterial infections. ACS Omega 3(6): 6912-6930.

Arshia JA, Faheem A, Khan KM, Shah S and Perveen S 2019 Benzophenone esters and sulfonates: synthesis and their potential as antiinflammatory agents. Med. Chem. 15 (2): 162-174.

Bouarab-Chibane L, Forquet V, Lantéri P, Clément Y, Léonard-Akkari L, Oulahal N, Degraeve P and Bordes C 2019 Antibacterial properties of polyphenols: characterization and QSAR (quantitative structure-activity relationship) models. Front. Microbiol. 10: 829.

Díaz-Carrillo JT, Díaz-Camacho SP, DelgadoVargas F, Rivero IA, López-Angulo G, Sarmiento-Sánchez JI and Montes-Avila J 2018 Synthesis of leading chalcones with high antiparasitic, against Hymenolepis nana, and antioxidant activities. Braz. J. Pharm. Sci. 54(3): e17343. .
Du Q, Yang Y, Guo L, Tian M, Ge X, Tian Z, Zhao L, Xu Z, Li J and Liu Z 2019 Fluorescent half-sandwich phosphinesulfonate iridium(III) and ruthenium(II) complexes as potential lysosome-targeted anticancer agents. Dyes Pigm. 162: 821830.

El-Ansari MA, Ibrahim LF and Sharaf M 2019 Natural phenolics: a source of anticancer agents. Egypt Pharmaceut. J. 18:1-7.

Fernandes RA, Gangani AJ and Kunkalkar RA 2020 Metal-free annulative hydrosulfonation of propiolate esters: synthesis of 4-sulfonates of coumarins and butenolides. New J. Chem. 44(10): 39703984.

Grosso S, Radaelli F, Fronza G, Passarella D, Monti D and Riva S 2019 Studies on the laccase-catalyzed oxidation of 4-hydroxychalcones. Adv. Synth. Catal. 361(11): 2696-2705.

Kanabar D, Farrales P, Gnanamony M, Almasri J, Abo-Ali EM, Otmankel Y, Shah H, Nguyen D, El Menyewi M, Dukhande VV, D'Souza A and Mutha A 2020 Structural modification of the aryl sulfonate ester of cjoc42 for enhanced gankyrin binding and anti-cancer activity. Bioorganic Med. Chem. Lett. 30(4): 126889.

Krishna CM, Kolla JN, Asha S and Reddy TSK 2020 In vitro anti-HIV-1 activity of ethyl gallate. Virus Dis. 31: 22-27.

Krishna P 2018 Chemoselective synthesis of 5amino-7-bromoquinolin-8-yl sulfonate derivatives and their antimicrobial evaluation. Phosphorus Sulfur Silicon Relat. Elem. 193(10): 685-690.

Lutz M, Fuentes E, Ávila F, Alarcón M and Palomo I 2019 Roles of phenolic compounds in the reduction of risk factors of cardiovascular diseases. Molecules 24(2): 366.

Oliveira RN, Mancini MC, Oliveira FCS, Passos TM, Quility B, Thiré RMS and Mcguiness GB 2016 FTIR analysis and quantification of phenolsand flavonoids of five commercially available plants extracts 
used in wound healing. Revista Matéria 21(3): 767-779.

Ovonramwen OB, Owolabi BJ, Oviawe AP and Falodun A 2020 Synthesis and antimicrobial activity of 5-chloro-1-ethyl2methylimidazole-4-sulfonyl-8quinolinoxide. J. Chem. Health Risks 10(3): 233-242.

Rendošová M, Vargová Z, Sabolová D, Imrichová N, Hudecová D, Gyepes R, Lakatoš B and Elefantová K 2018 Silver pyridine-2-sulfonate characterisation, DNA binding, topoisomerase I inhibition, antimicrobial, and anticancer response. J. Inorg. Biochem. 186: 206-216.

Rosa GP, Seca AML, Barreto MC, Silva AMS and Pinto DCGA 2019 Chalcones and flavanones bearing hydroxyl and/or methoxyl groups: synthesis and biological assessments. Appl. Sci. 9(14): 2846.

Sato VH, Chewchinda S, Parichatikanond W and Vongsak B 2020 In vitro and in vivo evidence of hypouricemic and antiinflammatory activities of Maclura cochinchinensis (Lour.) Corner heartwood extract. J. Tradit. Complement. Med. 10(1): 85-94.

Shakhatreh MA, Al-Smadi ML, Khabour OF, Shuaibu FA, Hussein EI and Alzoubi KH 2016 Study of the antibacterial and antifungal activities of synthetic benzyl bromides, ketones, and corresponding chalcone derivatives. Drug Des. Devel. Ther. 10: 3653-3660.

Shubhalaxmi SH, Zschille C, Jayarama A and Bhat KS 2013 Crystal structure studies and thermal characterization of novel 4hydroxychalcone derivative. Chem. Sci. Trans. 2(3): 841-846.

Sigma-Aldrich (330248 Aldrich) $2021 \quad 5-$ Chloro-1-ethyl-2-methylimidazole.

Specification Sheet FTNMR (PDF) https://www.sigmaaldrich.com/catalog/prod uct/aldrich/330248 Accessed April 2021.

Tingare YS, Akula SB, Shen MT, Su C, Ho SY, Tsai SH, Lina YF and Li WR 2018 The effect of cis-trans configurational difference on the performance of pyridylimine-based ruthenium sensitizers. Dalton Trans. 47(25): 8356-8363.

Trout GE 1966 Imidazoles and imidazole metabolism. PhD thesis, University of the Witwatersrand, Johannesburg, South Africa.

Yen GC, Cheng HL, Lin LY and Hsu CL 2020 The potential role of phenolic compounds on modulating gut microbiota in obesity. $J$. Food Drug. Anal. 28(2): 195-205.

Zargoosh Z, Ghavam M, Bacchetta G and Tavili A 2019 Effects of ecological factors on the antioxidant potential and total phenol content of Scrophularia striata Boiss. Sci. Rep. 9(1): 16021. 